\section{Investigation of Hepatitis C Virus Transmission Associated with Injection Therapy for Chronic Pain - California, 2015}

Monique A. Foster, $\mathrm{MD}^{1}$; Cheri Grigg, $\mathrm{DVM}^{2}$; Jaclyn Hagon, $\mathrm{MSN}^{3}$; Paige A. Batson, $\mathrm{MA}^{3}$, Janice Kim, $\mathrm{MD}^{4}$; Mary Choi, $\mathrm{MD}^{2}$; Anne Moorman, $\mathrm{MPH}^{1}$; Charity Dean, $\mathrm{MD}^{3}$

On November 26, 2014, the California Department of Public Health (CDPH) contacted CDC concerning a report from the Santa Barbara County Public Health Department (SBPHD) regarding acute hepatitis $\mathrm{C}$ virus $(\mathrm{HCV})$ infection in a repeat blood donor. The patient, who was asymptomatic, was first alerted of the infection by the blood bank and had no traditional risk factors for $\mathrm{HCV}$ infection. The donor had a negative HCV nucleic acid test (NAT) 56 days before the first positive NAT test, and an investigation into the donor's health care exposures and other potential risk factors, including injection drug use, incarceration, and long-term hemodialysis within this narrow exposure window, was conducted by SBPHD.

One such exposure occurred at a doctor's office (clinic A) where the blood donor received an injection procedure as part of prolotherapy. Prolotherapy, also known as regenerative injection therapy, is an increasingly popular, injection-based complementary and alternative medical therapy used to treat chronic musculoskeletal pain (1). Common substances injected include hypertonic dextrose, phenol-glycerine-glucose, and morrhuate sodium, a mixture of saturated and unsaturated fatty acids from cod liver oil (1). In addition, some patients also received platelet rich plasma therapy, a method of prolotherapy that involves injection of autologous blood with a high platelet-to-plasma ratio (2). No formal practice guidelines have been established for prolotherapy treatment, and no formal training is required to deliver this service. The initial investigation into clinic A revealed infection control breaches that included reentering multidose medication vials with a used syringe, use of single-dose medication vials for multiple patients, poor hand hygiene and inconsistent glove use, and lack of aseptic technique when handling injection equipment and medication. Clinic A was advised to stop these practices, and staff members were educated on bloodborne pathogen transmission. A subsequent visit to clinic A revealed ongoing poor infection control practices by staff members. After this visit, the county health officer issued an order to close clinic $A$ immediately. A joint investigation into clinic A by SBPHD, $\mathrm{CDPH}$, and $\mathrm{CDC}$ was initiated to identify additional cases and determine the source of transmission.
Patients who visited clinic A during the preceding 10 months ( $\mathrm{n}=400)$ were notified through mailed letters about their potential exposure to $\mathrm{HCV}$, hepatitis $\mathrm{B}$ virus (HBV), and human immunodeficiency virus (HIV). SBPHD coordinated free testing through a local laboratory. Case-finding activities included review of medical records for patients who visited clinic A, review of state hepatitis surveillance records and crossmatching with clinic A records, and serologic HCV and HBV testing of staff members. Patients subsequently identified as having $\mathrm{HCV}$ infection were interviewed, and a blood specimen was sent to CDC for HCV genotype and phylogenetic testing.

In addition to the index patient, six other patients who received injections at clinic $\mathrm{A}$ were determined to have $\mathrm{HCV}$ infection by serologic testing. Among these six patients, five were unaware of their HCV infection status. Four of the patients without a prior $\mathrm{HCV}$ diagnosis or risk factors for $\mathrm{HCV}$ had injection procedures performed in clinic A on the same day as the index patient. A common injected substance used in all the infected patients was not identified through medical chart review, although documentation of injected local anesthesia was inconsistent. No new HBV or HIV infections were found.

Identification of a case of acute HCV infection in a frequent blood donor without other risk factors should be considered a sentinel event and should prompt public health investigation, because this could indicate a possible health care-associated infection (3). HCV transmission from health care exposures has been documented previously (Table) $(4,5)$. Many of these outbreaks are attributable to the same unsafe injection practices observed in clinic A, namely reuse of syringes to access medications used for multiple patients (5). Although hospitals have established infection control education, resources, and oversight, health care settings where complementary and alternative medical therapies are administered, especially those that involve injections, might benefit from infection control training and inclusion in health care-associated infection surveillance networks, such as CDC's National Healthcare Safety Network (G). All health care settings, including complementary medical settings where injections occur, should follow guidelines for safe injection practices ( 7 ).

\footnotetext{
${ }^{1}$ National Center for HIV/AIDS, Viral Hepatitis, STD, and TB Prevention, CDC; ${ }^{2}$ National Center for Emerging and Zoonotic Infectious Diseases, CDC; ${ }^{3}$ Santa Barbara County Public Health Department; ${ }^{4}$ California Department of Public Health.

Corresponding author: Monique Foster, ydg9@cdc.gov, 404-718-8561.
} 
TABLE. Health care-associated hepatitis C virus outbreaks reported to CDC, by setting - 2008-2015

\begin{tabular}{|c|c|c|c|c|c|}
\hline Setting & Year & State & $\begin{array}{l}\text { Persons notified } \\
\text { for screening* }\end{array}$ & $\begin{array}{l}\text { Outbreak- } \\
\text { associated } \\
\text { infections }^{\dagger}\end{array}$ & Known or suspected mode of transmission ${ }^{\S}$ \\
\hline \multicolumn{6}{|l|}{ Outpatient } \\
\hline Prolotherapy clinic & 2015 & CA & $<1,500$ & 5 & Syringe reuse \\
\hline Insulin infusion clinic & 2015 & CA & 92 & 9 & $\begin{array}{l}\text { Fingerstick device (lancet holder) designed for personal use } \\
\text { was reused on other patients; inadequate cleaning and } \\
\text { disinfection of glucometer before reuse }\end{array}$ \\
\hline Pain management clinic & 2015 & MI & 122 & 2 & Syringe reuse \\
\hline Cardiology clinic & 2015 & WV & $>2,000$ & 5 & Use of single-dose vials for $>1$ patient \\
\hline Hematology oncology clinic & 2012 & $\mathrm{Ml}$ & $>300$ & 10 & Specific lapses in infection control not identified \\
\hline Pain management clinic & 2011 & NY & 466 & 2 & Suspected syringe reuse \\
\hline Pain management clinic & 2010 & CA & 2,293 & 2 & Syringe reuse \\
\hline Clinic & 2010 & $\mathrm{FL}$ & 3,929 & 5 & Drug diversion \\
\hline Alternative medicine clinic & 2009 & FL & 163 & 9 & Syringe reuse \\
\hline Endoscopy clinics & 2009 & NY & 3,287 & 2 & Suspected syringe reuse \\
\hline $\begin{array}{l}\text { Ambulatory surgical centers (single- } \\
\text { purpose endoscopy clinics) }(n=2)\end{array}$ & 2008 & NV & $>60,000$ & 9 & Syringe reuse \\
\hline Cardiology clinic & 2008 & NC & 1,200 & 5 & Syringe reuse \\
\hline Total & - & - & $>75,000$ & 65 & - \\
\hline \multicolumn{6}{|l|}{ Long-term care } \\
\hline Skilled nursing & 2013 & ND & $>500$ & 46 & $\begin{array}{l}\text { Epidemiologic analysis suggested podiatry care, phlebotomy, } \\
\text { and nail care }\end{array}$ \\
\hline \multicolumn{6}{|l|}{ Hospital } \\
\hline Hospital & 2015 & UT & 7,217 & $>7$ & Drug diversion \\
\hline Hospital & 2012 & $\begin{array}{c}\mathrm{AZ} \\
\mathrm{GA} \\
\mathrm{KS} \\
\mathrm{MD} \\
\mathrm{MI} \\
\mathrm{NH} \\
\mathrm{NY} \\
\mathrm{PA}\end{array}$ & $>11,000$ & 45 & Drug diversion" \\
\hline Hospital-based surgery service & 2009 & $\mathrm{CO}$ & $>8,000$ & 26 & Drug diversion \\
\hline Total & - & - & $>26,217$ & $>78$ & - \\
\hline \multicolumn{6}{|l|}{ Hemodialysis facility } \\
\hline Outpatient & 2015 & NJ & 237 & 2 & $\begin{array}{l}\text { Multiple lapses in infection control identified, including hand } \\
\text { hygiene and glove use, vascular access care, medication } \\
\text { preparation, cleaning, and disinfection }\end{array}$ \\
\hline Outpatient & 2015 & NJ & 84 & 2 & $\begin{array}{l}\text { Multiple lapses in infection control identified, vascular access } \\
\text { care, medication preparation, cleaning, and disinfection }\end{array}$ \\
\hline Outpatient & 2015 & NJ & 98 & 2 & $\begin{array}{l}\text { Multiple lapses in infection control identified, including hand } \\
\text { hygiene and glove use, vascular access care, medication } \\
\text { preparation, cleaning, and disinfection }\end{array}$ \\
\hline Outpatient & 2015 & PA & 115 & 3 & $\begin{array}{l}\text { Multiple lapses in infection control identified, medication } \\
\text { preparation close to treatment area }\end{array}$ \\
\hline Outpatient & 2015 & PA & 130 & 3 & $\begin{array}{l}\text { Multiple lapses in infection control identified, medication } \\
\text { preparation close to treatment area }\end{array}$ \\
\hline Outpatient & 2015 & PA & 97 & 2 & $\begin{array}{l}\text { Multiple lapses in infection control identified, medication } \\
\text { preparation close to treatment area, use of single-dose vials } \\
\text { for one patient, no separation of dirty and clean areas }\end{array}$ \\
\hline
\end{tabular}

See table footnotes on next page. 
TABLE. (Continued) Health care-associated hepatitis C virus outbreaks reported to CDC, by setting $-2008-2015$

\begin{tabular}{|c|c|c|c|c|c|}
\hline Setting & Year & State & $\begin{array}{l}\text { Persons notified } \\
\text { for screening* }\end{array}$ & $\begin{array}{l}\text { Outbreak- } \\
\text { associated } \\
\text { infections }{ }^{\dagger}\end{array}$ & Known or suspected mode of transmission ${ }^{\S}$ \\
\hline Outpatient & 2015 & CA & 28 & 3 & Breaches in environmental cleaning and disinfection practices \\
\hline Outpatient & 2014 & WA & 186 & 3 & Breaches in environmental cleaning and disinfection practices \\
\hline Outpatient & 2014 & TN & 62 & 2 & Breaches in environmental cleaning and disinfection practices \\
\hline Outpatient & 2014 & NJ & 69 & 4 & Breaches in environmental cleaning and disinfection practices \\
\hline Outpatient & 2014 & NJ & 97 & 2 & Breaches in environmental cleaning and disinfection practices \\
\hline Outpatient & 2012 & PA & 66 & 18 & $\begin{array}{l}\text { Multiple lapses in infection control identified, including hand } \\
\text { hygiene and glove use, vascular access care, medication } \\
\text { preparation, cleaning, and disinfection }\end{array}$ \\
\hline Outpatient & 2012 & CA & 42 & 4 & Specific lapses in infection control not identified \\
\hline Outpatient & 2011 & GA & 89 & 6 & $\begin{array}{l}\text { Failure to maintain separation between clean and } \\
\text { contaminated workspaces }\end{array}$ \\
\hline Outpatient & 2010 & TX & 171 & 2 & Specific lapses in infection control not identified \\
\hline Outpatient & 2009 & MD & 250 & 8 & $\begin{array}{l}\text { Breaches in medication preparation and administration practices } \\
\text { Breaches in environmental cleaning and disinfection practices }\end{array}$ \\
\hline Hospital-based & 2009 & NJ & 144 & 21 & $\begin{array}{l}\text { Breaches in medication preparation and administration practices } \\
\text { Breaches in environmental cleaning and disinfection practices }\end{array}$ \\
\hline Outpatient & 2008 & NY & 657 & 9 & $\begin{array}{l}\text { Failure to consistently change gloves and perform hand } \\
\text { hygiene between patients; breaches in environmental } \\
\text { cleaning and disinfection practices }\end{array}$ \\
\hline Total & - & - & 2,622 & 96 & - \\
\hline
\end{tabular}

Abbreviations: $\mathrm{HBV}=$ hepatitis $\mathrm{B}$ virus; $\mathrm{HCV}=$ hepatitis $\mathrm{C}$ virus.

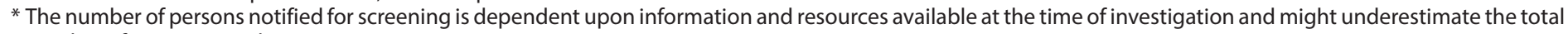
number of persons at risk.

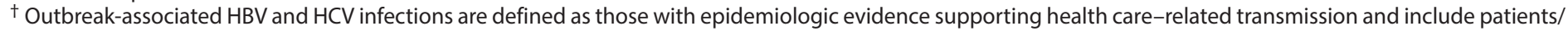

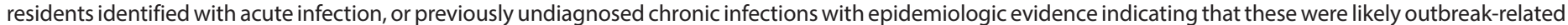

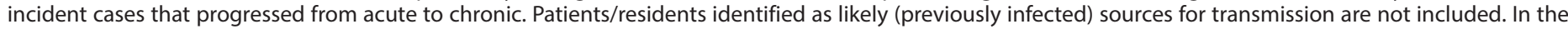

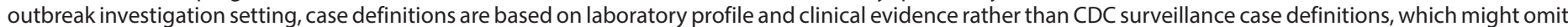

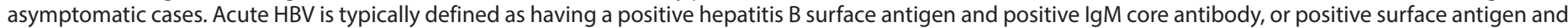

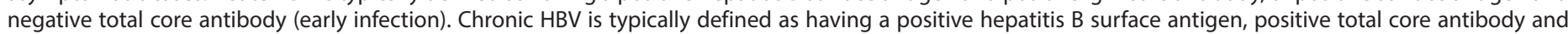

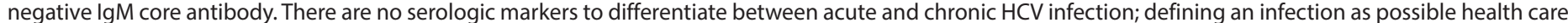

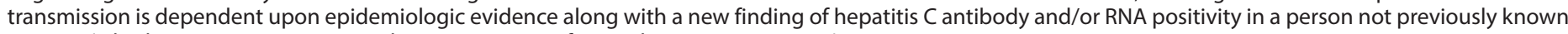
positive (whether or not symptoms or alanine aminotransferase elevation are present).

$\S$ All modes of transmission are patient-to-patient unless otherwise indicated.

ๆ Drug diversion is the shift of a prescribed substance, typically opioids, from the individual for whom it was prescribed to another person for illicit use.

\section{References}

1. Rabago D, Slattengren A, Zgierska A. Prolotherapy in primary care practice. Prim Care 2010;37:65-80. http://dx.doi.org/10.1016/j.pop.2009.09.013

2. Marx RE. Platelet-rich plasma (PRP): what is PRP and what is not PRP? Implant Dent 2001;10:225-8. http://dx.doi.org/10.1097/00008505-200110000-00002

3. CDC. Reporting incident HBC and HCV infections meeting CSTE acute case definition among repeat blood donors from blood collection centers to public health departments. Atlanta, GA: US Department of Health and Human Services, CDC; 2015. http://www.cdc.gov/hepatitis/ outbreaks/blooddonorinfections.htm

4. Thompson ND, Perz JF, Moorman AC, Holmberg SD. Nonhospital health care-associated hepatitis $\mathrm{B}$ and $\mathrm{C}$ virus transmission: United States, 1998-2008. Ann Intern Med 2009;150:33-9. http://dx.doi. org/10.7326/0003-4819-150-1-200901060-00007
5. CDC. Healthcare-associated hepatitis $B$ and $C$ outbreaks reported to the Centers for Disease Control and Prevention (CDC) in 2008-2015. Atlanta, GA: US Department of Health and Human Services, CDC; 2015. http://www.cdc.gov/hepatitis/outbreaks/healthcarehepoutbreaktable.htm

6. CDC. Outpatient settings policy options for improving infection prevention. Atlanta, GA: US Department of Health and Human Services, CDC; 2015. http://www.cdc.gov/hai/pdfs/prevent/Outpatient-Settings-Policy-Options.pdf

7. CDC. Guideline for isolation precautions: preventing transmission of infectious agents in healthcare settings. Atlanta, GA: US Department of Health and Human Services, CDC; 2007. http://www.cdc.gov/hicpac/ pdf/isolation/Isolation2007.pdf 